\title{
Agronomic performance and yield of radish cultivars
}

\author{
Romário da Silva Moreira ${ }^{1}$, Marlei Rosa dos Santos ${ }^{1}$, Ronildo Almeida de Sousa ${ }^{1}$, Rubenalto \\ da Silva Almeida', Francisco de Assis Gomes Junior'1, Warlington Aquilis Araujo Coelho ${ }^{1}$
}

\footnotetext{
${ }^{1}$ Universidade Estadual do Piauí, Campus de Uruçuí, Uruçuí, Piauí, Brasil. E-mail: romariomoreira524@gmail.com, marleirs@yahoo.com.br, ronildoalmeida@hotmail.com, rubenaltosilva@hotmail.com, franciscojr.21@hotmail.com, coelhowarlington@gmail.com
}

Received: 04/02/2019; Accepted: 03/05/2019.

\begin{abstract}
The radish is a Brassicaceae with small size, adapted to regions with mild temperatures between 13 and $20{ }^{\circ} \mathrm{C}$ and short days. However, there are cultivars adapted to high-temperature conditions, which has allowed the cultivation of this tuberous vegetable throughout the year, even in tropical regions. The present work had as objective evaluate the agronomic performance and yield of six cultivars of radish, in Uruçuí - PI. The experimental design was in randomized blocks, with four replicates and six cultivars. Harvest was performed according to the cycle of each cultivar. Number of leaves per plant, fresh and dry mass of shoot and root, diameter, and root length and yield were evaluated. The cultivars Margaret Queen and Crimson Gigante presented better root development, both in diameter and length, and obtained higher productivity per ha, being these two the most indicated for the region. The Sparkler cultivar was one of the ones that produced the highest fresh mass of the aerial part, but it obtained lower commercial roots yield, being the least indicated for the municipality of Uruçuí-PI.
\end{abstract}

Keywords: Raphanus sativus, development of plants, production.

\section{Desempenho agronômico e produtividade de cultivares de rabanete}

\section{RESUMO}

O rabanete é uma Brassicaceae de pequeno porte, adaptada a regiões com temperaturas amenas entre 13 e $20{ }^{\circ} \mathrm{C}$ e dias curtos. No entanto, existem cultivares adaptados a condições de temperaturas elevadas, o que tem possibilitado o cultivo desta hortaliça tuberosa durante todo ano, inclusive em regiões tropicais. O presente trabalho teve como objetivo avaliar o desempenho agronômico e a produtividade de seis cultivares de rabanete, no município de Uruçuí - PI. O delineamento experimental utilizado foi em blocos casualizados, com quatro repetições e seis cultivares. A colheita foi realizada de acordo com o ciclo de cada cultivar. Avaliou-se número de folhas por planta, massa fresca e seca da parte aérea e da raiz, diâmetro e comprimento da raiz e produtividade. Os cultivares Margaret Queen e Crimson Gigante apresentaram melhor desenvolvimento de raiz, tanto em relação ao diâmetro quanto ao comprimento, e obtiveram maior produtividade por ha, sendo estes dois os mais indicados para o município. O cultivar Sparkler foi um dos que produziram maior massa fresca da parte aérea, porém, obteve menor produção de raízes comerciais, sendo o menos indicado para o município de Uruçuí-PI.

Palavras-chave: Raphanus sativus, desenvolvimento de plantas, produção. 


\section{Introduction}

The radish (Raphanus sativus L.), belonging to the Brassicaceae family, is an annual vegetable of low size, is considered a good option for the rural producer, being one of the crops with the shortest cycle among the vegetables (Steiner et al., 2009). The main root is edible and presents reddish outer color and white inner color, with a spicy taste (Moreira et al., 2008). Nutritionally, radish is rich in vitamins and has significant antioxidant activity (Camargo et al., 2007).

The Brazilian consumer market has become increasingly demanding regarding the diversification, quality, and price of the products, which has led the vegetable producers to the use of cultivars and hybrids of high productivity and quality (Antonini et al., 2002). Therefore, there is a need to use cultivars adapted to each region, since the choice of cultivar is decisive for the success of the cultivation system adopted (Lima et al., 2004) and to obtain better product quality and higher productivity. Also, knowledge on factors related to plant growth and development allows planning of cropping techniques (Pedó et al., 2010b) and provides information on the effect of the environment on the development and production of different species or cultivars (Andrade et al., 2005).

Radish is a crop that is best adapted to sowing in autumn-winter, mild temperatures between 13 and $20^{\circ} \mathrm{C}$ and short days, conditions that keep the plant in a vegetative state for longer (Filgueira, 2008). However, there are already cultivars and hybrids more resistant to high temperatures, which has made possible the cultivation throughout the year, even in warmer regions (Vidigal and Pedrosa, 2007).

There are microclimatic differences within the same agricultural zone (Possas et al., 2012). The effects of these microclimatic differences on the performance of a given crop are of great importance; therefore, before making definitive recommendations of genotypes in different locations, it is necessary to verify the performance of the cultivars available for that region (Pereira et al., 2015).

The evaluation of the adaptability of different cultivars can provide conditions to obtain better results, both in the volume of production and in the final quality of the food provided to the consumer, because the production of the crops is directly associated with the conditions of the environment in which they occur and the genetic characteristics of each cultivar or species (Pedó et al., 2010a).

There are several cultivars of radish on the market, with roots of different shapes and colors, but the characteristics sought by seed companies and growers are large roots, resistant to disease and cracking, uniform interior and perfection globular shape. The radish cultivars, Saxa (red), Sparkler (red with white tip), Cometa (red), Gigante Sículo (red) and Hybrid Margaret Queen (red) are all rounded root (ISLA, 2006). The cultivars of greater acceptance are those that produce roots with round shape, with bright red peel coloration and white pulp (Filgueira, 2008).

In some regions of Brazil, vegetable producers have no tradition in the cultivation of radish, so few studies have been carried out on the crop, lacking information on their cultivation, production, and development, mainly in the municipality of Uruçuí-PI. With the migration of people from southern Brazil to the south of Piaui, there is a need for more information regarding the performance of this culture to meet local demand. In this way, the present work had the objective to evaluate the agronomic performance and yield of six radish cultivars in the city of Uruçuí - PI.

\section{Material and Methods}

The experiment was carried out in the experimental station of the Piaui State University - UESPI, Campus of Uruçuí-PI, located in the southern region of the state of Piaui $\left(07^{\circ} 13^{\prime} 46^{\prime \prime} \mathrm{S}, 44^{\circ} 33^{\prime} 22^{\prime \prime} \mathrm{W}\right.$ and the average altitude of $167 \mathrm{~m}$ ). During the conduction of the experiment, the mean values of temperature and relative air humidity ranged from 24 to $28{ }^{\circ} \mathrm{C}$ and from 37 to $48 \%$, respectively. There was no rainfall during the experiment period.

The experimental design was in randomized blocks, with four replications and six treatments, represented by the different radish cultivars: Apolo; Hybrid Margaret Queen; Sparkler; Crimson Gigante; Vip Crimson Seleção Especial and Novela. All cultivars have a rounded root.

Before starting the experiment, soil samples were collected in the $0-20 \mathrm{~cm}$ layer for the chemical characterization, and the main results are shown in Table 1. Based on the nutrient requirements of the radish (Vidigal and Pedrosa, 2007) and the chemical characteristics of the soil (Table 1), $30 \mathrm{~g} \mathrm{~m}^{-2}$ of NPK formulation 10-10-10, $10 \mathrm{~g} \mathrm{~m}^{-2}$ of potassium chloride, $33 \mathrm{~g} \mathrm{~m}^{-2}$ of single superphosphate, $4.5 \mathrm{~kg} \mathrm{~m}^{2}$ of bovine manure were applied as soil fertilization. Fertilization was applied to the soil surface and incorporated up to 15 $\mathrm{cm}$ deep, one day before the sowing. According to the soil analysis (Table 1), it was not necessary to apply limestone for $\mathrm{pH}$ correction, which was at 6.7.

Sowing was carried out on May 19, 2018, in furrows at $1.0 \mathrm{~cm}$ depth and $15 \mathrm{~cm}$ spacing between furrows. After the germination and establishment of the plants, when they were $5 \mathrm{~cm}$ high, thinning of plants was performed keeping the spacing of $5 \mathrm{~cm}$ between plants in the furrow. Irrigation was performed manually and daily using a watering can, and weed control was performed whenever necessary. 
Table 1. Results of the soil analysis in depth of 0-20 cm. Uruçuí-PI, UESPI, 2018.

\begin{tabular}{|c|c|c|c|}
\hline Attributes & Results & Attributes & Results \\
\hline $\mathrm{pH}\left(\mathrm{H}_{2} \mathrm{O}\right)$ & 6.7 & SBS (\%) & 94.9 \\
\hline Organic matter $\left(\mathrm{g} \mathrm{kg}^{-1}\right)$ & 15.5 & $\mathrm{AS}(\%)$ & 0.0 \\
\hline$P\left(m g m^{-3}\right)$ & 109.8 & $\mathrm{Ca}(\%)$ & 79.9 \\
\hline $\mathrm{K}^{+}\left(\mathrm{cmol}_{\mathrm{c}} \mathrm{dm}^{-3}\right)$ & 0.29 & $\operatorname{Mg}(\%)$ & 11.8 \\
\hline $\mathrm{Ca}^{+2}\left(\mathrm{cmol}_{\mathrm{c}} \mathrm{dm}^{-3}\right)$ & 7.19 & $\mathrm{~K}(\%)$ & 3.2 \\
\hline $\mathrm{Mg}^{+2}\left(\mathrm{cmol}_{\mathrm{c}} \mathrm{dm}^{-3}\right)$ & 1.06 & $\mathrm{~S}\left(\mathrm{mg} \mathrm{dm}^{-3}\right)$ & 0.98 \\
\hline $\mathrm{Al}^{+3}\left(\mathrm{cmol}_{\mathrm{c}} \mathrm{dm}^{-3}\right)$ & 0.0 & $\mathrm{Fe}\left(\mathrm{mg} \mathrm{dm}^{-3}\right)$ & 21.59 \\
\hline $\mathrm{H}^{+}+\mathrm{Al}^{+3}\left(\mathrm{cmol}_{\mathrm{c}} \mathrm{dm}^{-3}\right)$ & 0.46 & $\operatorname{Mn}\left(\mathrm{mg} \mathrm{dm}^{-3}\right)$ & 39.9 \\
\hline $\mathrm{SB}\left(\mathrm{cmol}_{\mathrm{c}} \mathrm{dm}^{-3}\right)$ & 8.54 & $\mathrm{Cu}\left(\mathrm{mg} \mathrm{dm}^{-3}\right)$ & 0.7 \\
\hline $\mathrm{CEC}\left(\mathrm{cmol}_{\mathrm{c}} \mathrm{dm}^{-3}\right)$ & 9.0 & $\mathrm{Zn}\left(\mathrm{mg} \mathrm{dm}^{-3}\right)$ & 9.7 \\
\hline
\end{tabular}

$\mathrm{P}, \mathrm{K}, \mathrm{Cu}, \mathrm{Fe}, \mathrm{Zn}$ and $\mathrm{Mn}$ : Mehlich-l extractor; $\mathrm{Al}, \mathrm{Ca}, \mathrm{Mg}$ : $\mathrm{KCl}$ extractor $1 \mathrm{~mol} / \mathrm{L} ; \mathrm{S}\left(\mathrm{Ca}\left(\mathrm{H}_{2} \mathrm{PO}_{4}\right) 20.01 \mathrm{~mol} / \mathrm{L}_{3} \mathrm{SB}=\mathrm{Ca}{ }^{+2}+\mathrm{Mg}{ }^{+2}+\right.$ $\mathrm{K}^{+}+\mathrm{Na}^{+} ; \mathrm{H}^{+}+\mathrm{Al}^{+3}$ : Calcium Acetate extractor $0.5 \mathrm{M}, \mathrm{pH}$ 7.0; $\mathrm{CEC}=\mathrm{SB}+\mathrm{H}^{+}+\mathrm{Al}^{+3}$; O.M.: Walkley-Black humid digestion; SBS: Soil Base Saturation; AS: Aluminum Saturation.

The harvest was carried out according to the crop cycle. The cultivars Apollo, Hybrid Margaret Queen, Vip Crimson and Novela, were harvested at 30 days after planting (DAP), and the cultivars Sparkler and Crimson Gigante at 32 DAP. The useful plot of $0.25 \mathrm{~m}^{2}$ was collected in the central area of each plot of $1.0 \mathrm{~m}^{2}$. After harvesting, the plants were washed for removal of soil residue and later divided into the shoot and root parts.

The number of leaves and the fresh mass of the aerial part were determined using a $0.001 \mathrm{~g}$ precision scale. The plants were then placed in paper bags and kept in an oven at $70^{\circ} \mathrm{C}$ for $72 \mathrm{~h}$; after this period, were again weighed to determine the dry mass of the aerial part, and the results were expressed in grams per plant $\left(\mathrm{g} \mathrm{pl}^{-1}\right)$. The diameter and length of all roots were determined using a digital caliper, and the results were expressed in $\mathrm{mm}$. The roots were cut in transverse slices and weighed in a $0.001 \mathrm{~g}$ precision scale to determine the fresh root mass and later placed in a paper bag in an oven at $70^{\circ} \mathrm{C}$ for $72 \mathrm{~h}$ and reweighed to determine root dry mass $\left(\mathrm{g} \mathrm{root}^{-1}\right)$. Based on the total mass per $\mathrm{m}^{2}$ of shoot and roots, yield $\left(\mathrm{t} \mathrm{ha}^{-1}\right)$ was calculated.

The data were submitted to variance analysis, and the comparison of the means of cultivars was performed by the Tukey test, at $5 \%$ probability, using the software Assistat 7.7 (2013).

\section{Results and Discussion}

It was verified that there was a significant difference ( $\mathrm{P}<0.01)$ between the cultivars for the number of leaves, shoot fresh and dry mass, and yield of fresh shoot mass (Table 2).

The Crimson Gigante cultivar presented a higher number of leaves per plant $(7,18)$ but did not differ from cultivar Sparkler $(6,81)$. The Novel cultivar $(5,66)$ was the one that presented a smaller number of leaves, not differing only from Hybrid Margaret Queen, with 5.76 leaves per plant (Table 2). Similar results were found by Melo et al. (2014); Silva et al. (2015) and Silva et al. (2017), which obtained an average number of 7.2, 6.9 and 8.48 leaves per plant, respectively, in the Crimson Gigante cultivar.

Guerra et al. (2017), studying the agronomic performance of radish in the Amazonian conditions in the rural community of Tabocal, Santarém - PA, with an average annual temperature of $25.9{ }^{\circ} \mathrm{C}$, spacing $0.10 \mathrm{x}$ $0.10 \mathrm{~m}$, observed 7.45 leaves per plant for the cultivar Sparkler. Schuster et al. (2012), studying the influence of photoperiod and solar radiation intensity on the growth and production of radish roots in the city of Guarapuava - PR, found 6.66 leaves per plant for Vip Crimson cultivar.

According to Linhares et al. (2010), the number of leaves is essential, considering that this organ in the plant is the place where the photosynthetic process responsible for producing photoassimilates occurs that will be sent to the productive organs of the plant. The number of leaves is directly related to the nutrient content available in the soil and mainly with the morphological characteristics of each cultivar and may also present variations according to the growing cycle (Bonela et al., 2017).

In this work, all cultivars received the same fertilization and were sown on the same day, so the genetic characteristics of each were expressed in response to the climate conditions, mainly at the temperature, which was close to $27^{\circ} \mathrm{C}$ during the growing period. It was observed that some cultivars are more adapted to the climatic conditions of the Uruçuí PI, with higher temperatures, since, according to Filgueira (2008), the radish is better adapted in autumnwinter planting with temperatures between 13 and $20^{\circ} \mathrm{C}$. 
About to the fresh and dry mass of the aerial part, the Sparkler cultivar had the highest mean values (32.34 and $2.12 \mathrm{~g} \mathrm{plant}^{-1}$, respectively) (Table 2). Also, the Novel cultivar presented lower fresh and dry mass (5.80 and $0.49 \mathrm{~g} \mathrm{plant}^{-1}$, respectively), which was expected due to the lower number of leaves (Table 2).

As for the yield of fresh shoot mass in $\mathrm{t} \mathrm{ha}^{-1}$, the Sparkler cultivar had the highest average $\left(21.37 \mathrm{t} \mathrm{ha}^{-1}\right)$, but did not differ from Vip Crimson cultivar (15.56 $\mathrm{t}$ ha $\left.{ }^{1}\right)$, while the Novel cultivar $\left(3.96 \mathrm{t} \mathrm{ha}^{-1}\right)$ presented lower productivity of fresh mass per ha, and hybrid Margaret Queen, with $9.69 \mathrm{t} \mathrm{ha}^{-1}$ (Table 2). These two cultivars also had the lowest number of leaves per plant.

The results of the variance analysis showed a significant difference $(\mathrm{P}<0.01)$ between cultivars for the variables root diameter and length, fresh and dry root mass, and yield (Table 3 ).

The radish cultivars that presented larger average root diameters were Margaret Queen, Crimson Gigante, and Novel, with diameters of $25.17 ; 23.81$ and 22.81 $\mathrm{mm}$, respectively, and the Sparkler cultivar presented a smaller diameter (9.27 mm) (Table 3).

These results were lower than those found by Oliveira et al. (2005), Salgado et al. (2006) and Vittil et al. (2007), which obtained an average root diameter of $35 \mathrm{~mm}$ using Sakata No. 19 cultivar, Hybrid No. 19 and Sparkler cultivar, respectively, when cultivated under organic fertilization and with the location of the experiments in the Seropédica - RJ and Pelotas - RS, with an average annual temperature of $23^{\circ} \mathrm{C}$. According to Costa et al. (2006), variations in soil moisture and temperature during plant development may impair root yield and quality.

About the length, Crimson Gigante cultivar was the one with the longest root length $(33.37 \mathrm{~mm})$, not statistically different from the cultivars Margaret Queen (29.28 mm) and Apolo (28.65 mm), and Novel cultivar presented lower root length $(23.95 \mathrm{~mm})$, differing only from cultivars Crimson Gigante and Margaret Queen (Table 3).

Table 2. Mean values of number of leaves per plant (NL), shoot fresh mass (SFM), shoot dry mass (SDM) and shoot fresh mass yield (SFY) of six radish cultivars. Uruçuí-PI, UESPI, 2018.

\begin{tabular}{ccccc}
\hline Cultivar & NL & $\begin{array}{c}\text { SFM } \\
\left(\mathrm{g} \mathrm{plant}^{-1}\right)\end{array}$ & $\begin{array}{c}\text { SDM } \\
\left(\mathrm{g} \mathrm{plant}^{-1}\right)\end{array}$ & $\begin{array}{c}\text { SFY } \\
\left(\mathrm{t} \mathrm{ha}^{-1}\right)\end{array}$ \\
\hline Apolo & $6.34 \mathrm{bc}$ & $17.27 \mathrm{~b}$ & $1.13 \mathrm{bc}$ & $14.74 \mathrm{~b}$ \\
Margaret Queen & $5.76 \mathrm{~cd}$ & $10.14 \mathrm{bc}$ & $0.66 \mathrm{~cd}$ & $2.69 \mathrm{bc}$ \\
Sparkler & $6.81 \mathrm{ab}$ & $32.34 \mathrm{a}$ & $2.12 \mathrm{a}$ & $1.37 \mathrm{a}$ \\
Crimson Gigante & $7.18 \mathrm{a}$ & $18.20 \mathrm{~b}$ & $1.28 \mathrm{~b}$ & $10.39 \mathrm{~b}$ \\
Vip Crimson & $6.43 \mathrm{~b}$ & $16.96 \mathrm{~b}$ & $1.09 \mathrm{bcd}$ & $3.96 \mathrm{c}$ \\
Novela & $5, .6 \mathrm{~d}$ & $5.80 \mathrm{c}$ & $0.49 \mathrm{~d}$ & 12.62 \\
\hline Means & 6.36 & 16.78 & 1.13 & 21.64 \\
CV $(\%)$ & 4.10 & 28.01 & 23.41 & 3.4071 \\
Block & 0.2931 & 30.9701 & 0.0517 & $142.5879 * *$ \\
Cultivars & $1.3825^{* *}$ & $327.2481^{* *}$ & 0.0696 & 7.4557
\end{tabular}

** Significant at $1 \%$ probability by $\mathrm{F}$ test. Means followed by the same letter in the column do not differ from each other by the Tukey test, at $5 \%$ probability.

Table 3. Mean values of root diameter (RD), root length (RL), root fresh mass (RFM), root dry mass (RDM) and root yield (ROY) of six radish cultivars. Uruçuí-PI, UESPI, 2018.

\begin{tabular}{cccccc}
\hline Cultivar & $\begin{array}{c}\text { RD } \\
(\mathrm{mm})\end{array}$ & $\begin{array}{c}\text { RL } \\
(\mathrm{mm})\end{array}$ & $\begin{array}{c}\text { RFM } \\
\left(\mathrm{g} \mathrm{root}^{-1}\right)\end{array}$ & $\begin{array}{c}\text { RDM } \\
\left(\mathrm{g} \mathrm{root}^{-1}\right)\end{array}$ & $\begin{array}{c}\text { ROY } \\
\left.(\mathrm{t} \mathrm{ha})^{-1}\right)\end{array}$ \\
\hline Apolo & $17.27 \mathrm{~b}$ & $28.65 \mathrm{abc}$ & $10.50 \mathrm{bc}$ & $0.42 \mathrm{ab}$ & $5.89 \mathrm{~b}$ \\
Margaret Queen & $25.17 \mathrm{a}$ & $29.28 \mathrm{ab}$ & $13.03 \mathrm{ab}$ & $0.43 \mathrm{ab}$ & $11.12 \mathrm{a}$ \\
Sparkler & $9.27 \mathrm{c}$ & $24.78 \mathrm{bc}$ & $3.68 \mathrm{c}$ & $0.20 \mathrm{~b}$ & $1.79 \mathrm{c}$ \\
Crimson Gigante & $23.81 \mathrm{a}$ & $33.37 \mathrm{a}$ & $18.84 \mathrm{a}$ & $0.61 \mathrm{a}$ & $8.32 \mathrm{ab}$ \\
Vip Crimson & $17.55 \mathrm{~b}$ & $28.11 \mathrm{bc}$ & $8.69 \mathrm{bc}$ & $0.38 \mathrm{ab}$ & $6.10 \mathrm{~b}$ \\
Novela & $22.81 \mathrm{a}$ & $23.95 \mathrm{c}$ & $10.72 \mathrm{abc}$ & $0.40 \mathrm{ab}$ & $6.55 \mathrm{~b}$ \\
\hline Means & 19.31 & 28.02 & 10.91 & 0.41 & 6.63 \\
CV $(\%)$ & 10.72 & 7.54 & 32.70 & 26.62 & 19.67 \\
\hline Block & 22.5039 & 7.3039 & 16.0323 & 0.0112 & 7.0709 \\
Cultivars & $139.9603 * *$ & $46.1245^{* *}$ & $99.7624^{* *}$ & $0.0676^{* *}$ & $37.7852^{* *}$ \\
Error & 4.2884 & 4.4592 & 12.7192 & 0.0116 & 1.6987 \\
\hline
\end{tabular}

** Significant at $1 \%$ probability by $\mathrm{F}$ test. Means followed by the same letter in the column do not differ from each other by the Tukey test, at $5 \%$ probability. 
In this work, there was no relationship between the greater number of leaves and greater diameter and length of roots. Confirmed the observations made by Dutra et al. (2014), the leaf development appears to be the main responsible for the accumulated weight of the roots (edible part) but, does not show a strong relationship with the diameter and length of the roots. The soil of the Experimental station of UESPI is of medium texture and presented $15.5 \mathrm{~g} \mathrm{~kg}^{-1}$ of O.M., which may have influenced the diameter and length of the roots. According to Bonela et al. (2017), the growth and development of radish roots are related to the organic matter content of the soil, and mainly to the physical characteristics, such as clay contents, that directly influence the porosity, providing better yields.

Regarding the fresh root mass, Crimson Gigante cultivar showed the highest mean fresh and dry root weight, with 18.84 and $0.61 \mathrm{~g}$, respectively, but did not differ from the fresh root mass of the cultivars Margaret Queen (13.03 g) and Novel (10.72 g). The root dry mass differed only from Sparkler cultivar, which presented lower root dry mass $(0.20 \mathrm{~g})$ and lower fresh root mass (3.68 g) (Table 3).

The hybrid Margaret Queen obtained higher commercial root yield (11.12 t ha-1), not statistically different from the Crimson Gigante cultivar (8.32 t $\left.\mathrm{ha}^{-1}\right)$. The Sparkler cultivar presented lower yield $(1.79 \mathrm{t}$ ha $^{-1}$ ) (Table 3). Linhares et al. (2010) and Batista et al. (2013), studying the yield of Crimson Gigante cultivar in an organic production system at a spacing of $0.20 \mathrm{x}$ $0.05 \mathrm{~m}$ in Mossoró - RN, obtained an average yield of 9.1 and $12.05 \mathrm{t} \mathrm{ha}^{-1}$, respectively. Guerra et al. (2017) observed yield of $16.12 \mathrm{t} \mathrm{ha}^{-1}$ with the cultivar Sparkler, showing that this cultivar is not recommended for the Uruçuí-PI region.

\section{Conclusions}

The radish cultivars Margaret Queen and Crimson Gigante showed better root development and higher yield when grown in the municipality of Uruçuí - PI, and therefore are the two most suitable for cultivation in the region.

The Sparkler cultivar has a high production of fresh shoot mass, but has a low yield of commercial roots, being the least suitable for cultivation in Uruçuí-PI.

\section{Bibliographic References}

Andrade, A.C., Fonseca, D.M., Lopes, R.S., Nascimento Júnior, D., Cecon, P.R., Queiroz, D.S., Pereira, D.H., Reis, S.T., 2005. Análise de crescimento do capim-elefante 'napier' adubado e irrigado. Ciência e Agrotecnologia, 29, 415-423.
Antonini, A.C.C., Robles, W.G.R., Tessarioli Neto, J., Kluge, R.A., 2002. Capacidade produtiva de cultivares de berinjela. Horticultura Brasileira, 20, 646-648.

Assistat beta, 2013. Sistema para Análise Estatística. Versão 7.7. Silva, F.A.S., DEAG-CTRN-UFCG, Campina Grande PB - Atualizado em 01/12/2013.

Batista, M.A.V., Bezerra Neto, F., Ambrosio, M.M.Q., Guimarães, L.M.S., Saraiva, J.P.B., Silva, M.L., 2013. Atributos microbiológicos do solo e produtividade de rabanete influenciados pelo uso de espécies espontâneas. Horticultura Brasileira, 31, 587-594.

Bonela, G.D., Santos, W.P.S., Sobrinho, E.S., Gomes, E.J.C., 2017. Produtividade e qualidade de raízes de rabanete cultivadas sob diferentes fontes residuais de matéria orgânica. Revista Brasileira de Agropecuária Sustentável, 7, 66-74.

Camargo, G.A., Consoli, L., Lellis, I.C.S., Mieli, J., Sassaki, E.K., 2007. Bebidas naturais de frutas perspectivas de mercado, componentes funcionais e nutricionais. Revista Brasileira de Engenharia de Biossistemas, 1, 179-195.

Costa, C.C., Oliveira, C.D., Silva, C.J., Timossi, P.C., Leite, I.C., 2006. Crescimento, produtividade e qualidade de raízes de rabanete cultivadas sob diferentes fontes e doses de adubos orgânicos. Horticultura Brasileira, 24, 118-122.

Dutra, M., Deboni, T.C., Volpi, P.S.B., Matias, J.F.G., Nesi, B.Z., 2014. Avaliação produtiva de rabanete submetido a preparados homeopáticos de tiririca Cyperus rotundus. Revista Brasileira de Agroecologia, 9, 151-159.

Filgueira, F.A.R., 2008. Novo manual de olericultura: agrotecnologia moderna na produção e comercialização de hortaliças. Universidade Federal de Viçosa, Viçosa, 421 p.

Guerra, A.M.N.M., Ferreira, J.B.A., Vieira, T.S., Franco, J.R., 2017. Desempenho agronômico e atividade fotossintética de rabanetes nas condições amazônicas. Revista Brasileira de Agropecuária Sustentável, 7, 24-31.

ISLA, 2006. Rabanetes variados para colorir a mesa. https://isla.com.br/cgi-

bin/news_noticias.cgi?id_artigo=390/Rabanete-variados-paracolorir-a-mesa (acessado 25 de agosto de 2018).

Lima, A.A., Miranda, E.G., Campos, L.Z.O., Cuznato Júnior, W.H., Melo, S.C., Camargo, M.S., 2004. Competição das cultivares de alface Vera e Verônica em dois espaçamentos. Horticultura Brasileira, 22, 314-316.

Linhares, P.C.F., Pereira, M.F.S., Oliveira, B.S., Henriques, G.P.S.A., Maracajá, P.B., 2010. Produtividade de rabanete em sistema orgânico de produção. Revista Verde, 5, 94-101.

Melo, F.N.B., Linhares, P.C.F., Silva, E.B.R., Negreiros, A.M.P.N., Dantas Neto, J.B., 2014. Desempenho produtivo do rabanete sob diferentes quantidades de palha de carnaúba mais esterco bovino em cobertura. Agropecuária Científica no Semi-Árido, 10, 47-52.

Moreira, D.A.L., Aveiro, M.C., Gonçalves, N.M., Veronka, D.A., Laura, V.A., Rodrigues, A.P.D.A.C., Pedrinho, D.R., 2008. Qualidade fisiológica de sementes de rabanete comercializadas em Campo Grande-MS. Horticultura Brasileira, 26, 1174-1177. 
Oliveira, F.L., Ribas, R.G.T., Junqueira, R.M., Padovan, M.P., Guerra, J.G.M., Almeida, D.L., Ribeiro, R.L.D., 2005. Desempenho do consórcio entre repolho e rabanete com précultivo de crotalária, sob manejo orgânico. Horticultura Brasileira, 23, 184-188.

Pedó, T., Lopes, N.F., Aumonde, T.Z., Saccaro, E.L., 2010a. Partição de assimilados e produção de três cultivares de rabanete (Raphanus sativus L.) durante o ciclo de desenvolvimento, in: $8^{\text {a }}$ Jornada de Pós-Graduação e Pesquisa/Educação e sustentabilidade. Revista Congrega Urcamp, ISSN: 1982-2960.

Pedó, T., Lopes, N.F., Moraes, D.M., Aumonde, T.Z., Saccaro, E.L., 2010b. Crescimento de três cultivares de rabanete (Raphanus sativus) ao longo da ontogenia das plantas. Tecnologia e Ciências Agropecuária, 4, 17-21.

Pereira, G.A.M., Oliveira, M.C., Braga, R.R., Silva, D.V., Oliveira, A.J.M., Fernandes, J.S.C., Altino Júnior, V.C., 2015. Crescimento de cultivares de cenoura em diferentes ambientes. Comunicata Scientiae, 6, 317-325.

Possas, J.M.C., Correa, M.M., Moura, G.B.A., Lopes, P.M.O., Caldas, A.M., Fontes Júnior, R.V.P., 2012. Zoneamento agroclimático para a cultura do pinhão-manso no Estado de Pernambuco. Revista Brasileira de Engenharia Agrícola e Ambiental, 16, 993-998.

Salgado, A.S., Guerra, J.G.M., Almeida, D.L., Ribeiro, R.L.D., Espindola, J.A.A., Salgado, J.A.A., 2006. Consórcios alface-cenoura e alface-rabanete sob manejo orgânico. Pesquisa Agropecuária Brasileira, 41, 1141-1147.

Schuster, M.Z., Kawakami, J., Broetto, D., Szymczak, L.S., Ramalho, K.R.O., 2012. Influência do fotoperíodo e da intensidade de radiação solar no crescimento e produção de tubérculos de rabanete. Revista Brasileira de Tecnologia Aplicada nas Ciências Agrárias, 5, 73-86.

Silva, A.F.A., Souza, E.G.F., Barros Júnior, A.P., Bezerra Neto, F., Silveira, L.M., 2017. Desempenho agronômico do rabanete adubado com Calotropis procera (Ait.) R. Br. em duas épocas de cultivo. Revista Ciência Agronômica, 48, 328336.

Silva, E.M.B., Cláudio, A.A., Rêgo, V.M., Silvério, A.T., 2015. Características produtiva do rabanete submetido a doses de cinza vegetal. Enciclopédia biosfera, 11, 421-432.

Steiner, F., Pinto Júnior, A.S., Zoz, T., Guimarães, V.F., Dranski, J.A.L., Rheinheimer, A.R., 2009. Germinação de sementes de rabanete sob temperaturas adversas. Revista Brasileira de Ciências Agrárias, 4, 430-434.

Vidigal, S.M., Pedrosa, M.W, 2007. Rabanete, in: Paula Júnior, T.J., Venzon, M., (Ed.), 101 Culturas: Manual de tecnologias agrícolas. EPAMIG, Belo Horizonte, p. 661-664.

Vittil, M.R., Vidal, M.B., Morselli, T.B.G.A., Faria, J.L.C, 2007. Resposta do rabanete a adubação orgânica em ambiente protegido. Revista Brasileira de Agroecologia, 2, 45-53. 